\title{
PENERAPAN BANTUAN HUKUM DI INDONESIA
}

\author{
Friska Anggi Siregar \\ (Dosen Luar Biasa Fakultas Syariah IAIN Langsa)
}

\begin{abstract}
All people must be treated equally in the law. Equality in law must be balanced with equal treatment. Legal assistance is the right of a person who is involved in a criminal case to be able to prepare a defense or counseling in upholding his rights as a suspect. Everyone has the right to receive legal assistance from an advocate, no one may be denied the right to obtain a legal defense in a legal state. Provision of legal assistance does not look at religious, ancestral, racial, ethnic, political beliefs, socio-economic strata, skin color and gender. Thus, justice will be realized for everyone.
\end{abstract}

Keywords: law, human right.

Abstrak: hukum (rechtsstaat) mengakui dan melindungi hak asasi manusia. Semua orang harus diperlakukan setara di hadapan hukum. equality before the law harus diimbangi dengan persamaan perlakuan. Bantuan Hukum merupakan hak seseorang yang tersangkut dalam perkara pidana untuk dapat mengadakan persiapan pembelaan atau penyuluhan dalam menegakkan hak-haknya sebagai tersangka. Setiap orang berhak menerima bantuan hukum dari advokad, tidak ada seorangpun yang boleh diabaikan hak untuk mendapat pembelaan hukum dalam suatu negara hukum. Pemberian bantuan hukum tidak memandang latar belakang agama, keturunan, ras, etnis, keyakinan politik, strata sosio-ekonomi, warna kulit dan gender. Dengan demikian akan terwujud keadilan bagi semua orang.

Kata Kunci: Hukum, Hak Asasi Manusia

\section{PENDAHULUAN}

Selama ini yang terjadi adalah adanya kesemrawutan dalam konsep bantuan hukum dalam bentuk ada kantor-kantor advokat yang mengaku sebagai lembaga bantuan hukum tetapi sebenarnya berpraktik komersial dan memungut fee yang menyimpang dari konsep pro bono publico yang sebenarnya merupakan kewajiban dari advokat. Untuk itu diperlukan undangundang bantuan hukum sebagai konsekuensi pengakuan konsep bantuan hukum dalam UU Advokat. Ditambah lagi melihat Pasal 34 ayat (1)
UUD 1945 pengakuan hak sipil, politik, ekonomi, sosial, dan budaya dari fakir miskin yang berarti adanya pengakuan terhadap hak untuk dibela oleh advokat atau pembela umum bagi fakir miskin, maka undang-undang bantuan hukum mutlak diperlukan dalam rangka mempertegas hak untuk memperoleh bantuan hukum bagi fakir miskin.

Sejauh ini, dukungan finansial bagi YLBHI diperoleh dari sumbangansumbangan luar negeri, seperti Amerika Serikat, Swedia, Belgia, Belanda, Australia dan Kanada. 
Anggapan keliru yang tersebar luas adalah bahwa seolah-olah segala urusan tentang bantuan hukum termasuk dukungan finansial dapat diserahkan kepada organisasi bantuan hukum itu sendiri dengan asumsi organisasi bantuan hukum mau membantu karena seseorang dikategorikan miskin padahal bantuan hukum adalah tanggung jawab negara. Oleh karena itu negara telah mengabaikan tugas konstitusionalnya untuk membiayai gerakan bantuan hukum dan tidak mengalokasikan anggaran tertentu dalam Anggaran Pendapatan dan Belanja Negara (APBN). Hal ini bertentangan dengan kewajiban negara untuk melindungi fakir miskin. Negara bertanggung jawab atas nasib fakir miskin atau masyarakat miskin.

Sebagaimana telah diuraikan sebelumnya perangkat hukum positif yang ada kurang memadai untuk menunjang konsep bantuan hukum sebagai hak konstitusional. Oleh karena itu bantuan hukum perlu dijabarkan lebih lanjut di dalam undang-undang bantuan hukum yang memuat konsep, fungsi, dan sifat dari bantuan hukum. Serta konsep bantuan hukum dinyatakan secara jelas dan tegas di dalam UUD 1945, agar hak konstitusional rakyat untuk memperoleh bantuan hukum dapat terjamin.

Dalam negara hukum (rechtsstaat) negara mengakui dan melindungi hak asasi manusia setiap individu. Pengakuan negara terhadap hak individu ini tersirat di dalam persamaan kedudukan di hadapan hukum bagi semua orang. Dalam suatu negara hukum semua orang harus diperlakukan sama di hadapan hukum (equality before the law). Persamaan di hadapan hukum harus diimbangi juga dengan persamaan perlakuan (equal treatment).

Kalau seorang yang mampu (the have) mempunyai masalah hukum, ia dapat menunjuk seorang atau lebih advokat untuk membela kepentingannya. Sebaliknya seorang yang tergolong tidak mampu (the have not) juga dapat meminta pembelaan dari seorang atau lebih pembela umum (public defender) sebagai pekerja di lembaga bantuan hukum (legal aid institute) untuk membela kepentingannya dalam suatu perkara hukum. Tidak adil bilamana orang yang mampu saja yang dibela oleh advokat dalam menghadapi masalah hukum, sedangkan fakir miskin tidak memperoleh pembelaan karena tidak sanggup membayar uang jasa (fee) seorang advokat.

Perolehan pembelaan dari seorang advokat atau pembela umum (access to legal counsel) adalah hak asasi manusia setiap orang dan merupakan salah satu unsur untuk memperoleh keadilan (access to justice) bagi semua orang (justice for all). Tidak ada seorang pun dalam negara hukum yang boleh diabaikan haknya untuk memperoleh pembelaan dari seorang advokat atau pembela umum dengan tidak memperhatikan latar belakangnya, seperti latar belakang agama, keturunan, ras, etnis, keyakinan politik, strata sosio-ekonomi, warna kulit dan gender.

Berdasarkan latar belakang masalah diatas, pemakalah mencoba untuk menjelaskan lebih rinci mengenai apa itu bantuan hukum dan 
bagaimana cara mendapatkan bantuan hukum.

\section{DEFENISI BANTUAN HUKUM}

Pengertian bantuan hukum dapat dibagi menjadi (3) yaitu:

1. Bantuan hukum yang dikaitkan dengan legal Aid

Menurut Adnan Buyung Nasution, pengertian bantuan hukum disini dimaksudkan adalah khusus bantuan hukum bagi golongan masyarakat yang berpenghasilan rendah atau dalam bahasa populer simiskin, ukuran kemiskinan sampai saat ini masih tetap merupakan masalah yang sulit dipecahkan, bukan saja bagi negaranegara berkembang bahkan negaranegara yang sudah majupun masih tetap menjadi masalah. ${ }^{127}$

2. Bantuan hukum yang dikaitkan dengan legal Assistance

Menurut todung Mulya lubis: "Legal Asisstance yang biasanya punya konotasi pelayanan hukum atas jasa hukum yang dilakukan oleh masyarakat Advokat kepada masyarakat mampu dan tidak mampu". ${ }^{128}$

Pada legal assistance yang mengandung pengertian yang lebih luas dari Legal ai, karena disamping menggunakan dan tujuan memberikan jasa bantuan hukum yang lebih tepat dengan pengertian yang kita kenal sebagai profesi advokat yang memberi bantuan

127 Adnan Buyung Nasution, Bantuan Hukum di Indonesia, Bantuan Hukum dan Politik Pembangunan, cet. Ke-1 (Jakarta: LP3ES, 1982), hal. 1.

128 Todung Mulya Lubis, Bantuan Hukum dan Kemiskinan Struktural, cet. Ke-1 (jakarta: Penerbit LP3ES, 1986), hal. 3. hukum kepada yang mampu dan kepada rakyat miskin.

3. Bantuan hukum yang dikaitkan dengan legal service

Jika dihubungkan dengan masalah litigasi pengertian ini sebenarnya tidak menggambarkan pengertian bantuan hukum, pengertian ini dapat diterima sebagai pelayanan hukum, bila bantuan hukum tersebut berhbungan dengan konsultasi hukum dan penyuluhan hukum yang diberikan kepada anggota masyarakat mampu dan tidak mampu.

Menurut Yahya harahap:

Selain untuk menerapkan hukum dan penghormatan kepada hak yang diberikan hukum untuk setiap orang, legal services dan operasinya, lebih cenderung untuk menyelesaikan setiap persengketaan dengan jalan menempuh cara perdamaian. ${ }^{129}$

\section{FUNGSI DAN TUJUAN BANTUAN HUKUM}

Tujuan pemberian bantuan hukum, tidak hanya diperuntukkan bagi orang-orang yang tidak mempunyai akses terhsdsp hukum, juga bagi mereka yang membutuhkan bantuan hukum.

Menurut pendapat Mauro Cappelletti;

Bantuan hukum oleh si miskin umumnya diartikan sebagaipemberian jasa-jasa hukum, kepada orang-orang yang tidak mampu untuk

129 M. Yahya harahap, Pembahasan Permasalahan dan penerapan KUHAP, Penyidik dan penuntut, cet. Ke-5, (Jakarta: Penerbit Sinar Grafik, 2003), hal. 344. 
menggunakan jasa-jasa advokat atau profesional lawyer. Meskipun motivasi ataupun alasan dari pada pemberian bantuan hukum kepada si miskin ini berbeda-beda dari jaman ke jaman, namun ada satu hal yang kiranya tidak berubah, sehingga merupakan satu benang merah, yaitu dasar kemanusiaan. 130

Menurut pendapat Barry

Metzger, bahwa :

Program bantuan hukum di negaranegara berkembang, pada umumnya mengambil arti dan tujuan yang sama seperti di barat, yang pada dasarnya terdiri dari dua bagian yaitu, pertama bahwa bantuan hukum yang efektif adalah merupakan syarat yang esensial untuk berjalannya fungsi maupun integritas peradilan dengan baik, dan yang kedua, bahwa bantuan hukum merupakan tuntutan dari rasa kemanusiaan. ${ }^{131}$

Bahkan lebih dari itu, Barry Metzger mencoba menambahkan alasan-alasan lain ;

1. Untuk membangun suatu kesatuan sistem hukum nasional.

2. Untuk pelaksanaan yang lebih efektif, dari pada peraturanperaturan kesejahteraan sosial untuk keuntungan si miskin.

3. Untuk menumbuhkan rasa tanggung jawab yang lebih besar dari pejbat-pejabat pemerintahan atau birokrasi kepada masyaraka

130 Mauro Capelletti, toword equal justice; A comperative studyof legal Aid modern societies, (New york: Dobbs Ferry ,1975), pg.26.

${ }^{131}$ Barry Matzger, legal Service to the Poor and National Development Objectives, dalam buku Legal Aid and World Poverty, ( preger Publishhers, 1974),pg. 5.
4. Untuk menumbuhkan partisipasipartisipasi masyarakat yang lebih luas ke dalam proses pemerintahan

5. Untuk memperkuat profesi hukum. ${ }^{132}$

Bagi Indonesia, arti dan tujuan program bantuan hukum, disamping memberikan bantuan pelayanan bantuan hukum kepada masyarakat yang membutuhkannya, juga untuk mendidik masyarakat dalam arti yang seluas-luasnya dengan tujuan menumbuhkan dan membina kesadaran akan hak-hak sebagai subyek hukum. ${ }^{133}$

\section{ISTILAH \& PERAN PENASEHAT HUKUM, PENGACARA DAN ADVOKAT}

Istilah Advocaat dan procureur yang terdapat dalam Reglement op de rechtelijke Organisatie en het Beleid der Justitie in Indonesia, Stb,1847 no. 23 jo Stb,1848 No.57, Reglemen yang biasadisebut R.O., terutama perihal dasr-dasar bperadilan, susunan dan kekuasaan badan-badan peradilan di Hindia Belanda. Sebagian dari R.O, tersebut hingga kini masih berlaku di indonesia, berdasarkan pasal II aturan perlihan UUD 1945, khususnya pasal 185 sampai pasal 192 dengan judul Van Advocaten en Procureurs. ${ }^{134}$

Istilah advocaat dan procureur yang terdapat dalam R.O., tersebut, menurut Martiman Prodjohamidjojo: ...namum sebenarnya dari berbagai

132 Adnan Buyung, Ibid., hal. 6.

133 Ibid , hal 7

134 Soejono Soekanto, Bantuan Hukum suatu Tinjauan Sosio Yuridis, cet. Ke-1, ( jakarta: Penerbit Ghalia Indonesia, 1983), hal. 72

168| Penerapan Bantuan Hukum Di Indonesia 
nama atau istilah bagi mereka yang mempunyai profesi itu, terdapat dua golongan yakni, mereka yang bergelar sarjana hukum, dan mereka yang tidak bergelar sarjana hukum, akan tetapi mempunyai keahlian khusus dibidang hukum, disebut recht kundige atau ahli hukum.Di jaman Hindia Belanda, golongan pertama disebut advocaten en procureur yang diatur dalam R.O. pasal 185 sampai dengan pasal 192. Dan golongan kedua disebut zaakwaarnemers... terakhir ini dikenal masyarakat sebagai pokrol bambu atau pembela dan pengacara, kemudian berkembang menjadi pengacara praktek, suatu nama yang lebih halus dari pada pokrol. ${ }^{135}$

Menurut R. Soerbakti, Advocaat dan procureur adalah:

Seorang advokat adalah seorang pembela penasehat, sedangkan seorang procureur adalah seorsng yang ahli dalam hukum acara perdata yang memberikan jasa-jasanya dalam mengajukan perkara-perkara kepada pengadilan dan mewakili orang-orang yang berpekara di muka pengadilan. ${ }^{136}$
Istilah
Penasehat
Hukum, menurut Luhut M.P. Pangaribuan, ada beberapa kekurangan daripada istilah penasehat hukum yaitu:

Penasehat hukum iti secara detonatif atau konotatif bermakna pasif, padahal peranan profesi itu bisa kedua-duanya yaitu pasif ketika hanya memberikan nasehat-nasehat hukum tertentu yang bisa berbentuk lisan atau tertulis (seperti legal opinion/audit), tetapi bisa

135 Martiman prodjohamidjojo, Penasehat dan Bantuan Hukum Indonesia ,cet. Ke-1, ( Jakarta: Penerbit Ghalia Indonesia, 1982, hal. 5 .

136 Ibid, hal. 7 aktif melakukan pemblaan (letigasi)termasuk ketika menjalankan kuasa dalam penyelesaian suatu kasus secara alternatif dispute resolution (ADR), seperti negoisasi, mediasi, arbitrasi. Demikian juga secara normatif sebagaimana telah diatur dalam R.O., seseorang Advocaten en Procureurs dapat bertindak baik secara pasif maupun aktif dalam mengurusyang dikuasakan kepadanya. ${ }^{137}$

Kelemahan lain dari penggunaan istilah penasehat hukum, menurut Abdurahman adalah:

Istilah penasehat hukum krang mencerminkan hubungan yang erat dan mendalam antara tersangka atau terdakwa dengan mereka yang memberikan bantuan hukum, bahkan kurang menimbulkan kesan adanya hak setiap orang untuk dibela. Disamping itu adalah sangat janggal sekali kalau seorang tersangka dalam posisinya yang gawatdan terdesak hanya cukup dibantu hanya dengan pemberian nasehat saja, padahal justru yang diinginkan adlah bantuan yang sedemikian mendesak, dimana pembantuannya tersebut diharapkan untuk menerjunkan dirinya bersamasama dengan tersangka dalam memecahkan persoalan yang dihadapi berkenaaan dengan suatu tuduhan (sangkaan). 138

Lasdin Wlas membedakan Advokat dan pengacara:

Advokad adalah seorang Yuris, seorang

137 Luhut. M.P. Pangaribuan, Concept of Court, (jakarta: penerbit jambatan, 1996), hal. 2 .

138 Abdurahman, Aspek-aspek Bantuan Hukum di Indonesia, ( jakarta: Cendana press, 1983), hal. 205 
ahli hukum sarjana hukum, sedangkan pengacara seorang ahli hukum atau bukan ahli hukum sarjana hukum. ${ }^{139}$

Untuk menghapus terjadinya perbedaan istilah, fungsi dan peranan penasehat hukum, pengacara, atau advokat dan untuk menggantikan perundang-undangan yang diskriminatif serta sudah tidak sesuai lagi dengan sistem ketatanegaraan yang berlaku, serta sekaligus untuk memberi landasan yang kokoh pelaksanaan tugas pengabdian advokat dalam kehidupan mesyarakat, maka dibentuk undang-undang No. 18 tentang Advokat.

Menurut ketentuan umum undang-undang no. 18 tahun 2003 tersebut memberikan pengertian bahwa:

Advokat adalah orang yang berprofesi meberikan jasa hukum, berupa konsultasi hukum, menjalankan kuasa, mewakili,, mendampingi, membela, dan melakukan tindakan hukum lain untuk keentingan hukum klien, baik di dalam maupun di luar pengadilan yang memenuhi persyaratan berdasarkan undang-undang.

\section{HAK TERSANGKA MENDAPATKAN BANTUAN HUKUM}

Hak tersangka untuk mendapatkan bantuan hukum, diatur dalam ketentuan pasal 35 sampai dengan pasal 38 undang-undang no. 14 tahun 1970 tentang ketentuan pokok kekuasaan kehakiman, sebagaimana tekah diubah terakhir dengan undangundang No. 4 tahun 2004 dan peraturan pelaksanaannya dalam

139 Lasdin Wlas, Cakrawala Advokat Indonesia, ( yokyakarta: penerbit liberty, 1989), hal. 4. undang-undang No. 8 tahun 1981, tentang hukum acara pidana (KUHAP), yang diatur dalam pasal 54 sampai dengan pasal 57 KUHAP.

Pasal 35 Undang-undang No. 14 tahun 1970 menyatakan:

Setiap orang yang tersangkut perkara berhak memperoleh bantuan hukum.

Pasal 36. menyatakan:

Dalam perkara pidana, seorang tersangka, terutama sejak saat dilakukan penangkapan dan/ atau penahanan berhak menghubungi dan meminta bantuan penasehat hukum.

Pasal 37 menyatakan:

Dalam memberikan bantuan hukum tersebut, pada pasal 36 diatas, penasehat hukum membantu melancarkan penyelesaian perkara dengan menjunjung tinggi pancasila, hukum, dan keadilan.

Pasal 38 menyatakan :

Ketentuan-ketentuan dalam pasal 35, 36, dan pasal 37, diatas diatur lebih lanjut dalam undang-undang.

Ketentuan dalam pasal 54 KUHAP, memberikan hak kepada tersangka atau terdakwa mendapatkan bantuan hukum sejak tahap pemeriksaan penyidikan dimulai, pada dasarnya baru pada tahap pemeriksaan penyidikan, memberikan hak kepada tersangka untuk mendapat bantuan hukum.

Ketentuan pasal 55 KUHAP menyatakan :

Untuk mendapatkan penasehat hukum tersebut dalam Psal 54, 


$\begin{array}{llr}\text { tersangka } \quad \text { atau } & \text { terdakwa } \\ \text { berhak memilih } & \text { sendiri } \\ \text { penasehat hukumnya. } & \end{array}$

Ketentuan pasal 56 menyatakan :

1. Jika tersangka atau terdakwa disangka atau didakwa, yang diancam dengan pidan amati atau ancaman lima belas tahun atau lebih mereka yang tidak mampu, yang diancam dengan lima tahun atau lebih, yang tidak mempunyai penasehat hukum sendiri, pejabat yang bersangkutan pada semua tingkat pemeriksaan, dalam proses peradilan wajib menunjuk penasehat hukum bagi mereka.

2. Setiap penasehat hukum yang ditunjuk wajib untuk bertindak sebagai mana dimaksud dalam ayat (1), memberikan bantuannya dengan Cuma-Cuma.

Ketentuan pasal 57 KUHAP menyatakan :

1. Tersangka atau terdakwa yang dikenakan penahanan berhk menghubungi pensehat hukumnya, sesuai dengan ketentuan undangundang ini.

2. Tersngka atau terdakwa yang berkebangsaan sing, yang dikenakan penahanan berhak menghubungi dan berbicara dengan perwakilan negaranya dalam menghadapi proses perkaranya.

\section{HAK UNTUK DIBELA OLEH ADVOKAT ATAU PEMBELA UMUM}

Pemerintah Indonesia telah melaksanakan dan mewujudkan suatu negara hukum dalam praktik beracara dalam perkara pidana, yaitu dengan ditetapkannya UU No. 8 /1981 tentang
Kitab Undang-Undang Hukum Acara Pidana (KUHAP) yang mengutamakan prinsip "Due Process of Law" dengan memberikan perlindungan hukum yang jelas terhadap tersangka dan terdakwa. Jaminan perlindungan atas hak konstitusional untuk dibela oleh advokat adalah penting dalam praktik peradilan dan ini berlaku untuk orang yang mampu dan juga untuk fakir miskin. Kalau di dalam praktik peradilan orang mampu dapat menggunakan jasa advokat untuk membela kepentingannya maka bagi fakir miskin harus juga ada pembelaan baik dari advokat atau pembela umum secara pro bono publico. Sehingga pembelaan oleh advokat atau pembela umum bagi orang mampu atau fakir miskin adalah sesuatu hal yang mendasar karena merupakan hak individu yang harus dijamin dalam konstitusi dalam kerangka persamaan di hadapan hukum.

Selanjutnya sebagaimana pemikiran W. Friedmann pengakuan terhadap perlakuan yang sama (equal treatment) terhadap individu di hadapan hukum mempunyai korelasi dengan pengakuan kebebasan individu (individual freedom). Oleh karena itu setiap orang berhak untuk mendapatkan perlindungan hukum dan menunjuk seorang atau lebih advokat atau pembela umum untuk membelanya.

Adanya pembelaan advokat terhadap tersangka atau terdakwa yang berhadapan dengan negara yang mempunyai perangkat yang lengkap, maka akan terjadi keseimbangan dalam proses peradilan (audi et alteram partem) sehingga dapat dicapai keadilan bagi semua orang (justice for 
all).

Tentang keadilan, Immanuel Kant mengungkapkan sebagai berikut: "If justice is gone, there is no reasons for a man to live longer on earth" (George P. Fletcher, 1998). Ungkapan Kant ini menunjukkan betapa pentingnya keadilan bagi kehidupan manusia sehingga seringkali hukum dianggap bertujuan mencari keadilan (justice).

Hak untuk dibela oleh seorang advokat atau pembela umum bagi semua orang tanpa ada perbedaan telah dijamin oleh UUD 1945 sebagaimana diatur dalam Pasal 27 ayat (1) UUD 1945, yaitu: "Segala warga negara bersamaan kedudukannya di dalam hukum dan pemerintahan dan wajib menjunjung hukum dan pemerintahan itu dengan tidak ada kecualinya".

Hak untuk dibela oleh advokat atau pembela umum juga merupakan hak asasi manusia dari setiap warga negara yang dijamin dalam Universal Declaration of Human Rights, International Covenant on Civil and Political Rights (ICCPR), dan Basic Principles on the Role of Lawyers. Salah satu negara yang juga menjamin hak untuk mendapatkan pembelaan dari advokat dalam konstitusinya adalah Amerika Serikat. Diatur dalam The Bill of Rights: Amendment VI, yang berbunyi sebagai berikut: "In all criminal prosecutions, the accused shall enjoy the right to a speedy and public trial, by an impartial jury of the State and district wherein the crime shall have been committed, which district shall have been previously ascertained by law, and to be informed of the nature and cause of the accusation; to be confronted with the witnesses against him; to have compulsory process for obtaining witnesses in his favor, and to have the Assistance of Counsel for his defence." 140

\section{PENUTUP}

Berdasarkan Pasal 34 ayat (1) UUD 1945 ditegaskan bahwa "Fakir miskin dan anak-anak yang terlantar dipelihara oleh negara". Berdasarkan ketentuan Pasal 34 ayat (1) UUD 1945 tersebut negara mengakui hak ekonomi, sosial, budaya, sipil dan politik dari fakir miskin.

Atas dasar pertimbangan tersebut, fakir miskin memiliki hak untuk diwakili dan dibela oleh advokat baik di dalam maupun di luar pengadilan (legal aid) sama seperti orang mampu yang mendapatkan jasa hukum dari advokat (legal service). Penegasan sebagaimana diambil dari Pasal 34 ayat (1) UUD 1945 memberikan implikasi bahwa bantuan hukum bagi fakir miskin pun merupakan tugas dan tanggung jawab negara dan merupakan hak konstitusional.

Di negara berkembang seperti Indonesia, adanya organisasi bantuan hukum merupakan hal yang penting, yaitu untuk membantu fakir miskin dalam menghadapi masalah-masalah hukum karena organisasi bantuan hukum ini dapat mengurangi kemungkinan fakir miskin tidak memperoleh bantuan hukum untuk membela kepentingan hukumnya baik di dalam maupun di luar pengadilan. Organisasi bantuan hukum dapat

140

http://jodisantoso.blogspot.com/2007/06/dasarkonstitusional-bantuan-hukum.html, $\quad 27$ November 2018. 
membantu fakir miskin untuk dapat memperoleh pengetahuan tentang hukum, hak asasi manusia, hak sipil dan politik, hak sosial, hak budaya, dan hak ekonomi. International Covenant on Civil and Political Rights diratifikasi Indonesia dengan Undang-Undang Nomor 12 Tahun 2005 dan International Covenant on Economic, Social and Cultural Rights (ICESCR) diratifikasi dengan Undang-Undang Nomor 1 Tahun 2005 untuk memperkuat kewajiban pemerintah/negara untuk membantu hak fakir miskin baik dalam bidang politik, sosial dan ekonomi, serta bantuan hukum.

Hambatan perundang-undangan yang dialami selama ini adalah tidak adanya jaminan untuk memperoleh pembelaan baik bagi orang mampu maupun fakir miskin baik di dalam UUD 1945 maupun di dalam KUHAP. 


\section{DAFTAR PUSTAKA}

Abdurahman, Aspek-aspek Bantuan Hukum di Indonesia, Jakarta: Cendana press, 1983.

Capelletti, Mauro, toword equal justice; A comperative studyof legal Aid modern societies, New york: Dobbs Ferry ,1975.

Harahap, M. Yahya harahap, Pembahasan Permasalahan dan penerapan KUHAP, Penyidik dan penuntut, cet. Ke-5, Jakarta: Penerbit Sinar Grafik, 2003.

http://jodisantoso.blogspot.com/2007/06/dasar-konstitusional-bantuan-hukum.html, 3 November 2011.

Lubis, Todung Mulya, Bantuan Hukum dan Kemiskinan Struktural, cet. Ke-1, Jakarta: Penerbit LP3ES, 1986.

Matzger, Barry, legal Service to the Poor and National Development Objectives, dalam buku Legal Aid and World Poverty, (preger Publishhers, 1974.

Nasution, Adnan Buyung , Bantuan Hukum di Indonesia, Bantuan Hukum dan Politik Pembangunan, cet. Ke-1, Jakarta: LP3ES, 1982.

Pangaribuan, Luhut. M.P., Concept of Court, jakarta: penerbit jambatan, 1996.

Prodjohamidjojo, Martiman, Penasehat dan Bantuan Hukum Indonesia ,cet. Ke-1, Jakarta: Penerbit Ghalia Indonesia, 1982.

Soekanto, Soejono, Bantuan Hukum suatu Tinjauan Sosio Yuridis, cet. Ke-1, Jakarta : Penerbit Ghalia Indonesia, 1983.

Wlas, Lasdin, Cakrawala Advokat Indonesia, Yokyakarta : penerbit liberty, 1989. 